\title{
PROPOSALS FOR TECHNICAL DEVELOPMENT OF HAMMER CRUSHERS APPLIED IN BIOGAS PLANTS
}

\author{
Zoltán Bártfai ${ }^{362}$ \\ László Tóth ${ }^{363}$ \\ István Szalkai ${ }^{364}$
}

\author{
https://doi.org/10.31410/itema.2018.1077
}

\begin{abstract}
Feeding of the reactors becomes one of the most important part in managing a Biogas plant, because it is a critical factor for the stable biogas production.

This article overviews all the experiences we could gain from a research work performed in a biogas plant, aiming the improvement of the applied technology, focusing on the solid input material crushing process.

The intensive abrasion causes serious problem in the hammer crusher, and because of this, breakdowns, operational failure, and economic damage can appear in the biogas plants quite often. Hammers wore rapidly causing inappropriate chopping. If the crushing is not effective, the fibrous material reduces the mixing efficiency that causes less gas production.

Within the frame of the research, we worked out the applicable technology for improving the abrasion resistance of the hummers of the crusher that caused improved reliability for not only the equipment, but the whole biogas plant as well.
\end{abstract}

Keywords: renewable energy production, biogas technology, circular economy, adequate repairing technology, plant management

\section{REALISED TECHNICAL PROBLEM}

$\mathrm{T}$ The NHSZ Biogas Tatabanya Ltd biogas plant use mixed materials to generate biogas. The most important part of the technology is the preparation of the fiber (mainly corn) for shredding. In our tests BHS Biogrinder RBG 08 type solid material mincing machine was applied. The machine shredding properties wasn't compliance at case of different input solid material. The fermentors vane usually was covered with long fiber materials. Those events make bad effect for mixing and fermentation process. On other hand the parts of the machine had intense changing period, because of the intensive wearing effect.

\section{The technical suggestions were at the following areas:}

- hard metal technology to avoid the intensive wearing

- the mentioned wearing parts hardened by hard metal technology

- operational test for long distance application ability

- economical analysis for return of investment (Bártfai et al, Mezögazdasági technika, 2015).

\footnotetext{
${ }^{362}$ Szent István University, Faculty of Mechanical Engineering, 2100 Gödöllő, Páter K. u.1 Hungary

${ }^{363}$ Szent István University, Faculty of Mechanical Engineering, 2100 Gödöllő, Páter K. u.1 Hungary

${ }^{364}$ Szent István University, Faculty of Mechanical Engineering, 2100 Gödöllő, Páter K. u.1 Hungary
} 


\section{INTRODUCTION OF BHS BIOGRINDER RBG 08 MACHINE}

Next figure shows the BHS Biogrinder RBG 08.

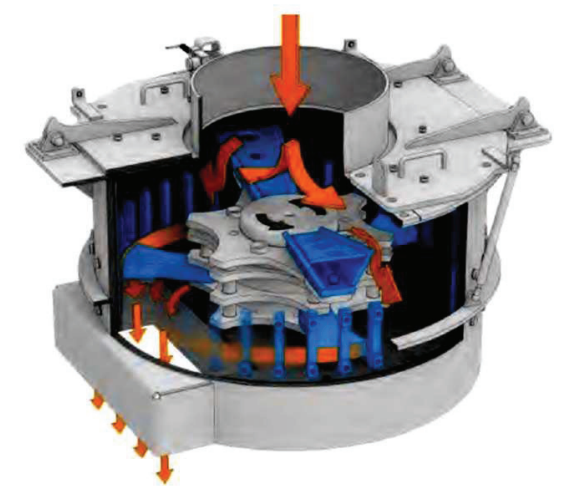

Fig. 1. The BHS Biogrinder RBG 08 parts

\section{The structure of grinding unit}

In the investigated biogas technology the biomass grinding is made by turning hammers. One machine is able to get 12 hammers. The material flow is supported by standing part; it is working like a standing knife. The turning parts are demonstrated at next figures.
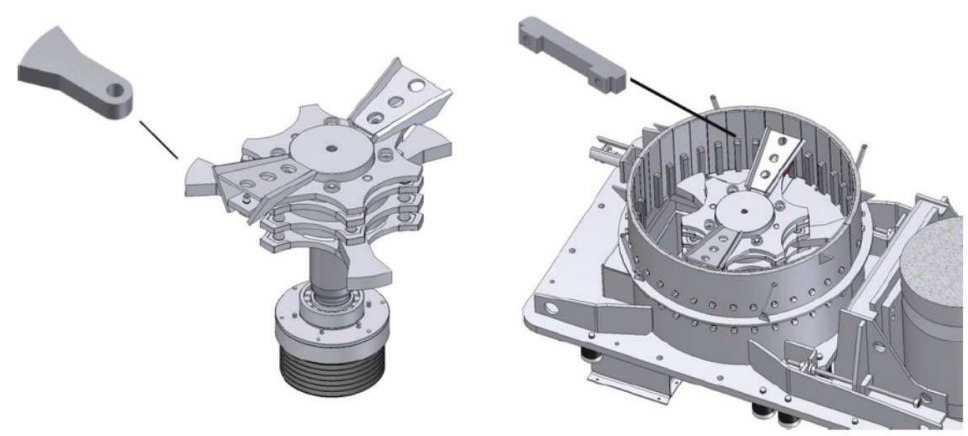

Fig 2. The BHS Biogrinder RBG 08 machine turning and fix parts

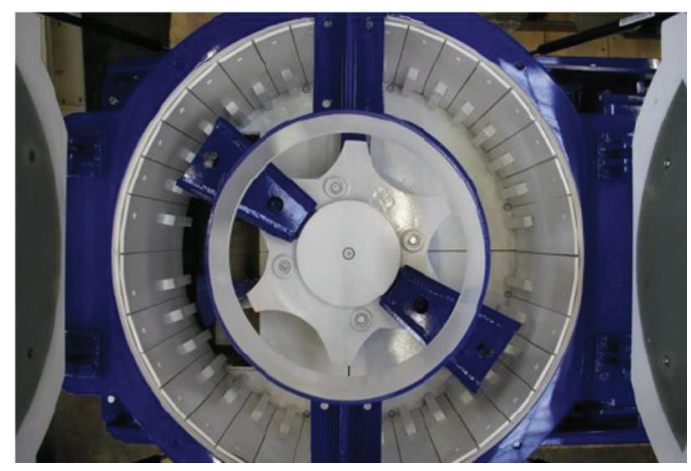

Fig 3. The turning and fix parts view from top 


\section{CAUSE OF THE PROBLEM: WEARING}

The parts of the machine touched by moving materials are wearing during the process caused by the friction. The input materials used for biogas generating are creating wearing, and the hammers form is changing continuously. Different input materials have different effect on the hammers in the case of wearing. The most intensive wearing are made by sand dust from manure (the dust content derives from the soil from the animals' leg).

This effect is typical on animal farms. The tested plant is a real source of danger, because the sand rate of the manure is high. Because of the wearing fix part and moving hammer have bigger distance, the shredding efficiency get worse.

Figure 4 and 5 show the difference between the original and used hammer.

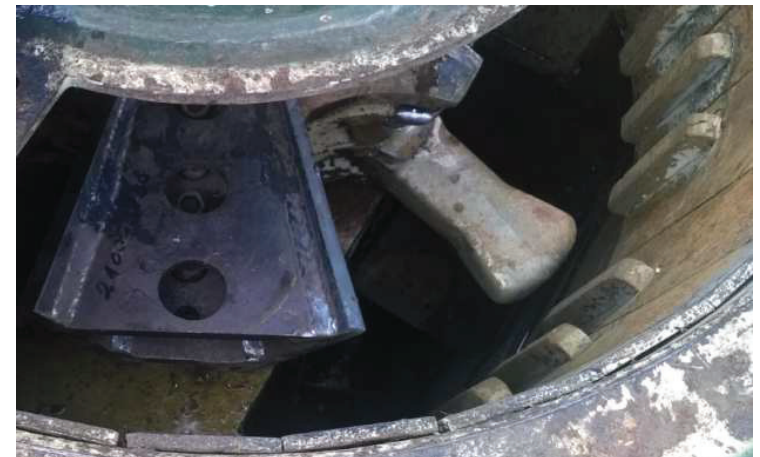

Fig 4. Distance between fix part and hammer, original (operational photo)

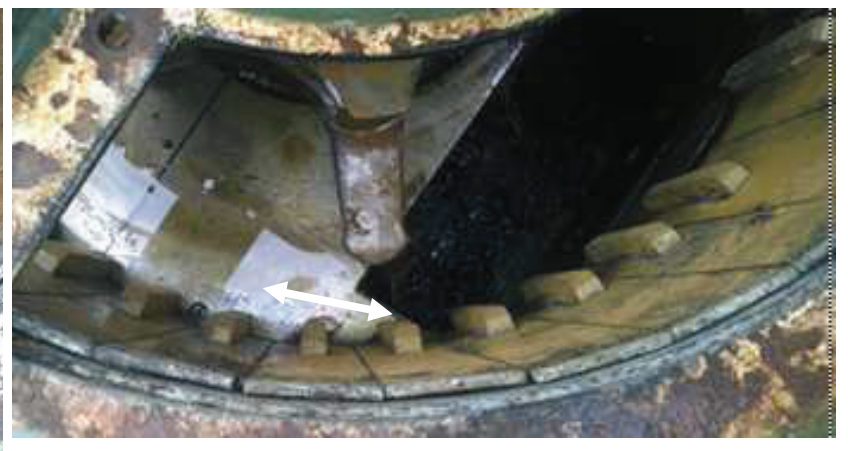

Fig 5. Distance with used hammer (operational photo)

Based on institute (Institut für Landtechnik und Tierhaltung, Weihenstephan, Freising) measurement we mentioned that the structure of manure from straw did not change using hammered shredding. This type of machine is not applicable for this type of materials.
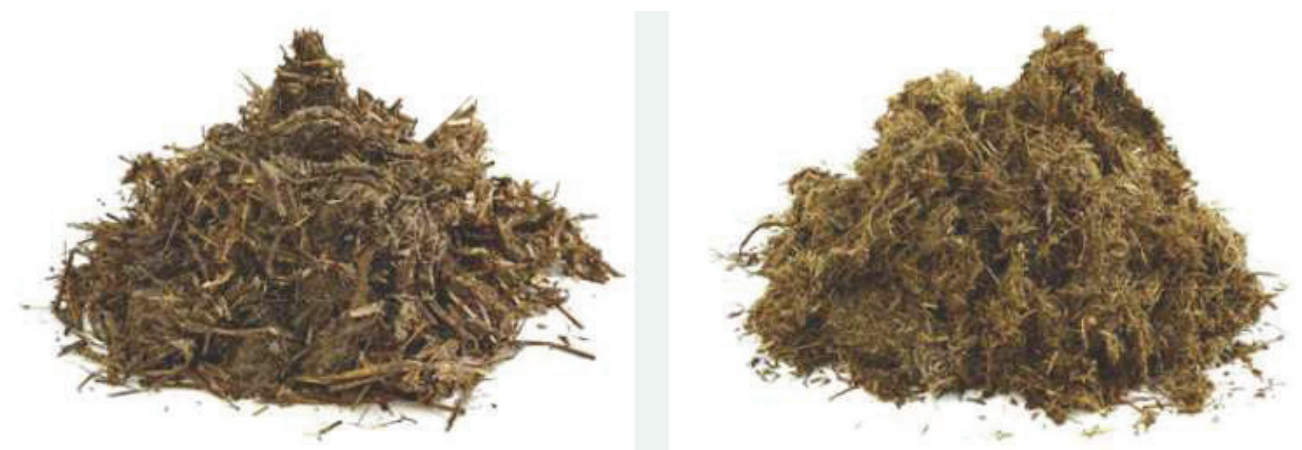

Fig 6. Manure from straw, before and after crushing 


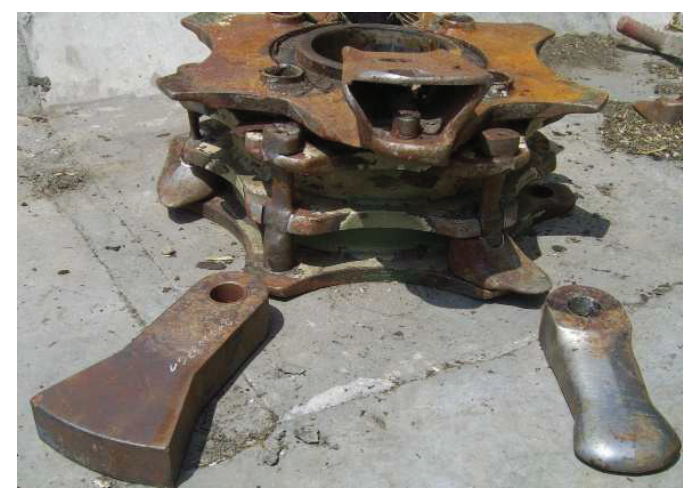

Fig 7. New and worn hammer

Fig. 8 and 9 shows the implemented and the stand-alone hammer. The form changing is too big for normal usage.

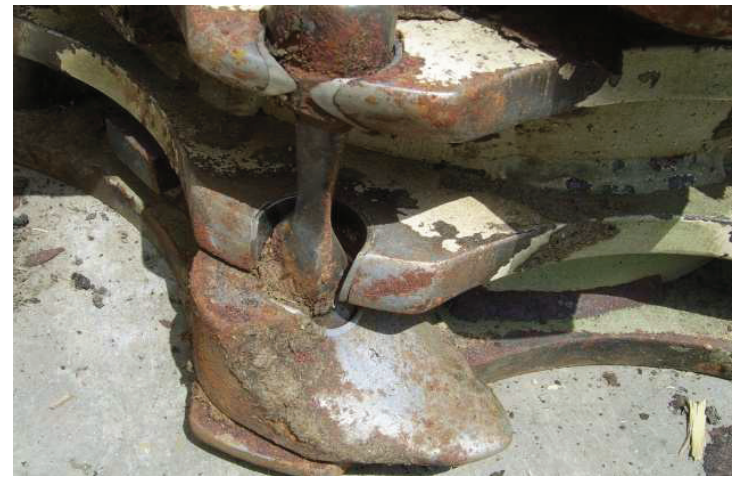

Fig 8. Used hammer

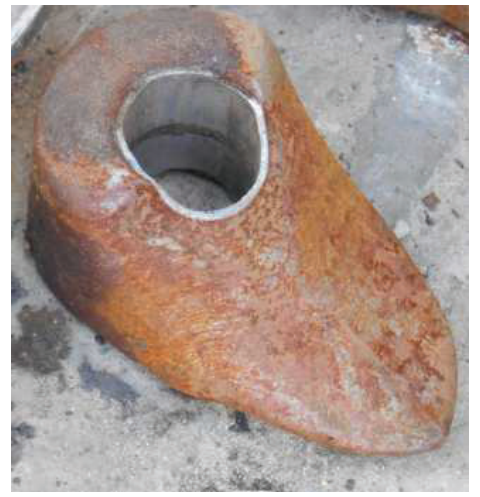

Fig 9. Unmounted used hammer

\section{HAMMER IMPROVEMENT BY HARD METAL WELDING}

Technologies for improving wear resistance:

- hard metal scattering is electric scattering

- hot metal spraying

- pottery reading

- application of porous ceramic

- abrasion resistant plastic spray

- manufacture of abrasion-resistant inserts, lining and parts

- spark welding

- heat treatment

- surface treatment

At Mechanical Engineering Faculty of Szent István University we created a technology plan and performed hard metal welding in order to improve the quality of the hammers.

For the testing process 3 hammers were prepared through 3 different welding processes:

1) The (-) signed hammer, the suture was parallel with the axle.

2) The (/) signed hammer the suture was at $45^{\circ}$ by the axle, at the same distance

3) The (X) signed hammer the suture was at $45^{\circ}$ by the axle but the opposite direction as / signed hammers. Sutures are at the same distance. 
Scattering is good for improve working period, and the optimal material usage is also important.

Fig 10. shows the hammers.

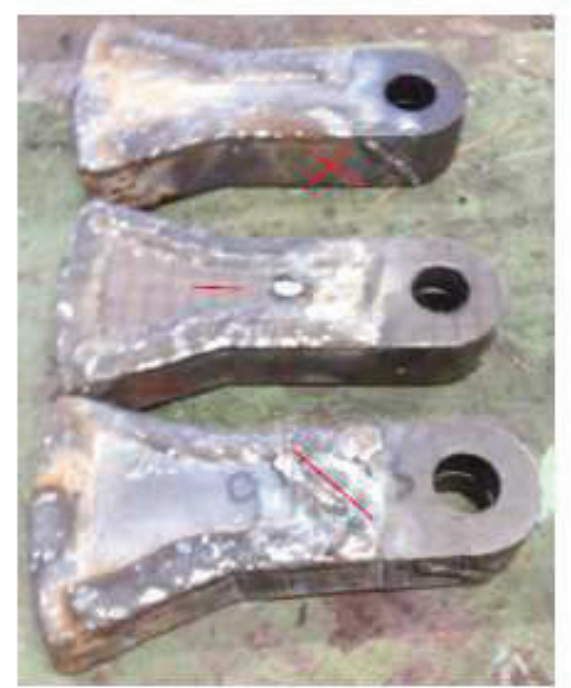

Fig 10. Hard metal welded hammers

\section{WELDING TECHNOLOGY}

Technical parameters:

\begin{tabular}{|c|c|c|c|}
\hline Sign & Standard & Chemical (\%) & Current \\
\hline \multirow{3}{*}{502} & & C: 5,50 & \\
& DIN 8555: E 10-GF-60 GR & Mn: 1,50 & $=+160 \mathrm{~A}$ \\
& & Cr: 40,0 & \\
& & Other: 2 & \\
\hline
\end{tabular}

\section{WEARING TEST}

The shredder was used at normal working conditions in the investigated biogas plant. After 600 working hours the wearing was estimated so extreme comparing normal conditions. At the first investigating phase the hammers were checked by a simple visual survey. We diagnosed there were no dangerous anomaly (broken parts, deformation, other structural injury).

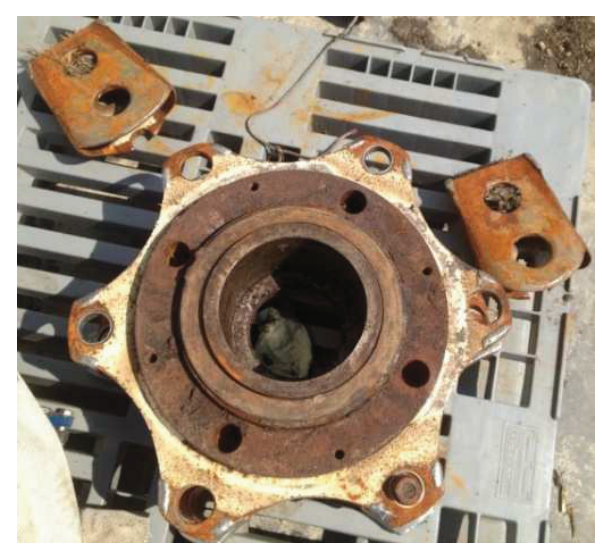

Fig 11. After 600 working hours, with hard metal welding 
Next figures show the worn hammers. As the pictures show there is no injury on the hammers.

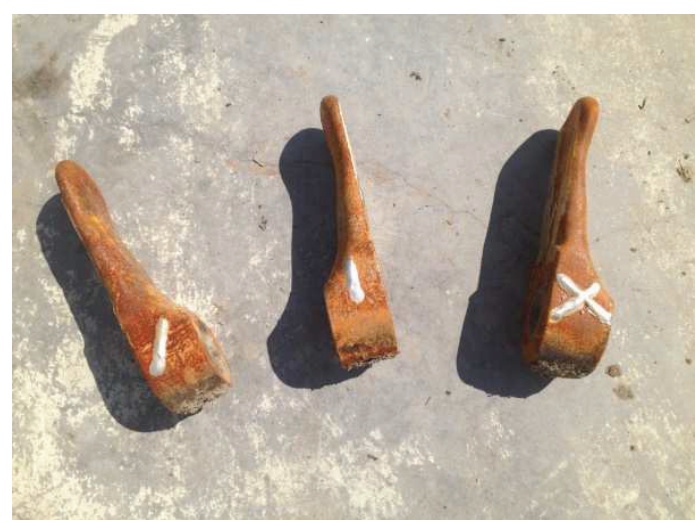

Fig 12. Hammers, side view

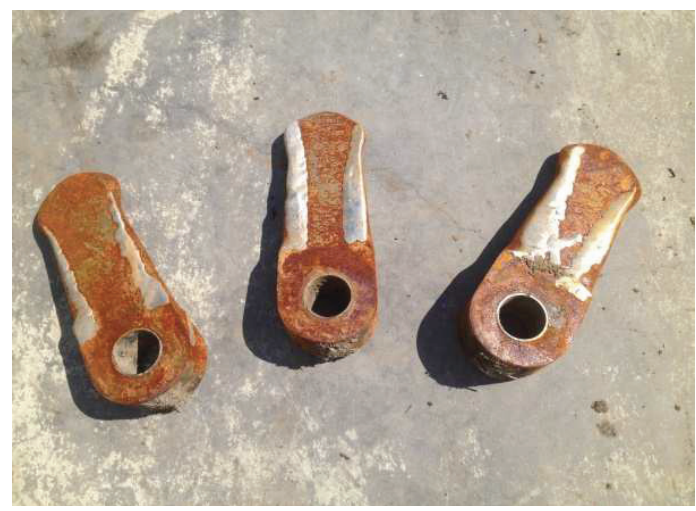

Fig 13. Hammers, top view

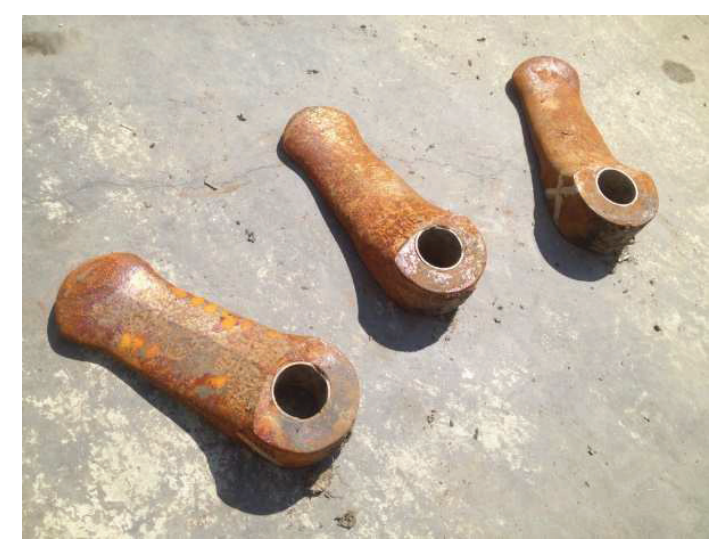

Fig 14. Hammers, button view

\section{METHOD}

For the further step of the scientific investigation we applied 3D scanning technology to measure the wearing size. The 3D scanner is a ZScanner 700 machine.

The 3D scanning method:

- define joints, surface net

- elementary body unit calculation

- surface units summary

The results are shown is the next figure and tables. 


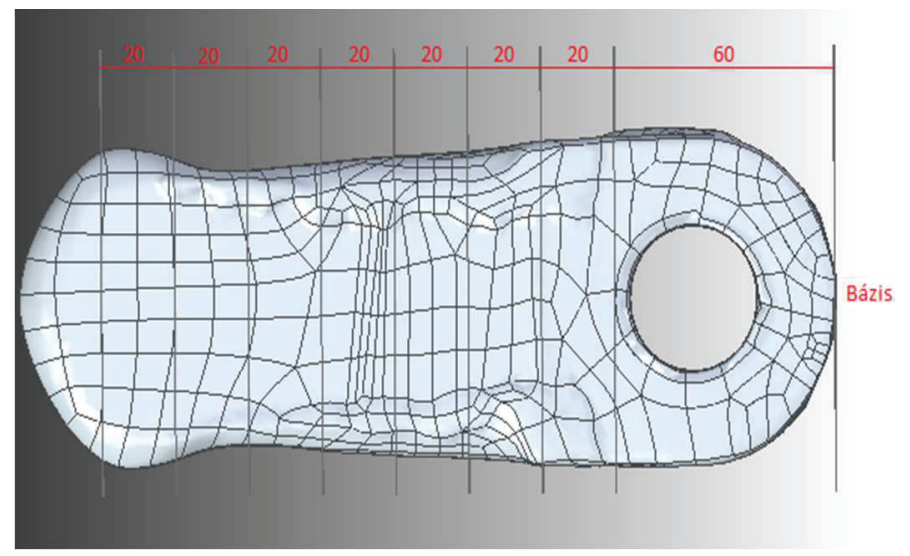

Fig 15. Scanned worn hammer

\section{RESULTS}

Table 1 shows the results for (/) signed hammer. This has the minimal size changing: $83,5 \%$ of the original size remained. The most intensive worn was realized on the hammer signed (-).

Table 1. Size changing

\begin{tabular}{|c|c|c|}
\hline \multicolumn{3}{|c|}{ Size (long) } \\
\hline \multicolumn{3}{|c|}{ [mm] } \\
\hline $\mathbf{( x )}$ worn & $\mathbf{( - )}$ worn & $(/)$ worn \\
\hline 219 & 218 & 222 \\
\hline $\mathbf{( x )}$ new & $\mathbf{( - )} \mathbf{n e w}$ & $(/)$ new \\
\hline 267 & 266 & 266 \\
\hline \multicolumn{3}{|c|}{ rate } \\
\hline $\mathbf{( x )}$ & $\mathbf{( - )}$ & $(/)$ \\
\hline 0,820 & 0,820 & 0,835 \\
\hline
\end{tabular}

Table 2 shows the width size changing on the different parts.

Table 2. Width changing

\begin{tabular}{|c|c|c|c|}
\cline { 2 - 4 } \multicolumn{1}{c|}{} & \multicolumn{3}{c|}{ Biggest width [mm] } \\
\hline From base [mm] & $(\mathbf{X})$ & $\mathbf{( - )}$ & $(/)$ \\
\hline 60 & 44,6 & 42,47 & 44,48 \\
\hline 80 & 32,66 & 30,26 & 32,54 \\
\hline 100 & 25,17 & 23,61 & 25,37 \\
\hline 120 & 22,07 & 20,2 & 22,37 \\
\hline 140 & 18,14 & 15,75 & 18,56 \\
\hline 160 & 15,4 & 13,26 & 15,8 \\
\hline 180 & 16,33 & 14,24 & 16,74 \\
\hline 200 & 17,12 & 14,75 & 17,82 \\
\hline Original width [mm] & 45 & 45 & 45 \\
\hline Worn width [mm] & 44,93 & 44,78 & 44,79 \\
\hline
\end{tabular}


We calculated the wear by the weight of the hammers. Weight can be calculated from the volume of the original and worn hammers. (Table 3.)

Table 3. Volume and weight changing

\begin{tabular}{|l|c|c|c|}
\cline { 2 - 4 } \multicolumn{1}{c|}{} & \multicolumn{3}{|c|}{ Volume $\left[\mathbf{m m}^{\mathbf{3}}\right] \mathbf{~ n e w}$} \\
\cline { 2 - 4 } & $\mathbf{( X )}$ & $\mathbf{( - )}$ & $(/)$ \\
\cline { 2 - 4 } & 1056435 & 1066941 & 1047621 \\
\cline { 2 - 4 } & $\mathbf{3}$ Volume $\left[\mathbf{m m}^{3}\right]$ worn \\
\cline { 2 - 4 } & $\mathbf{( X )}$ worn & $\mathbf{( - )}$ worn & $(/)$ worn \\
\hline Volume rate: & 357603 & 333335 & 358062 \\
\hline
\end{tabular}

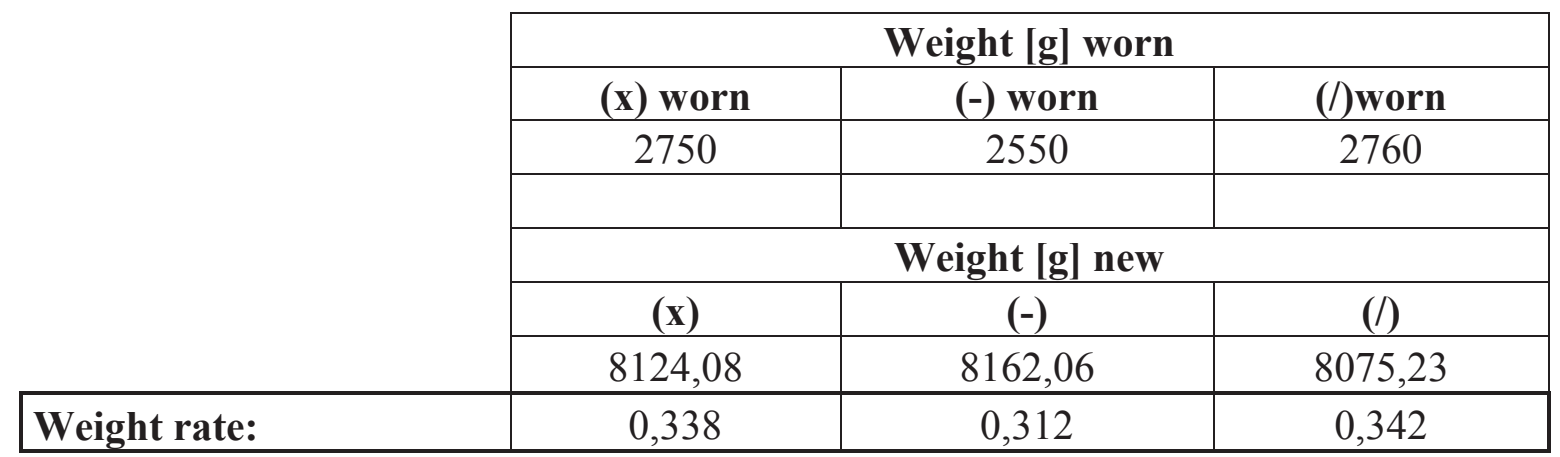

\section{SUMMARY}

Based on real factory operational tests we diagnosed that the hard metal welded hammers perform more effective and economic operating.

Based on the measurement results optimal solution based on welding suture seems to be the (/) signed hammer. So our recommend is applying this suture to improve the wearing resistance.

Our test shows that the button part wears more. Because of this we recommend to cover the whole button part of the hammers by hard metal.

\section{Acknowledgement}

This publication has been completed within the framework of project no. EFOP-3.6.1-16-20160016 focusing on training and research profiles with intelligent specializations on the Szarvas Campus of St Istvan University involving agricultural water management, hydroponic plant systems, alternative crop production related to improving precision machinery in agriculture.

\section{REFERENCES}

1. P. Korzenszky K- Petróczki: Energy and Quality Performance Investigation of Hammer Mill, MECHANICAL ENGINEERING LETTERS: R AND D: RESEARCH AND DEVELOPMENT 3: pp. 65-72. (2009)

2. Tóth L., Beke J., Bártfai Z., Szabó I., Hartdégen G.:Technikai, technológiai jellemzők a vegyes anyagokat felhasználó biogáz üzemekben Mezőgazdasági Technika, 2014/11.

3. L. Tóth-J.Beke-Z. Bártfai- I. Szabó-I. Oldal-L. Kátai: Critical technology factors of biogas plants using mixed $6^{\text {th }}$ International Conference on Biosystems Engineering 2015, Tartu, Észtország 
4. Bártfai Z-Tóth L- Oldal I-Szabó I- Beke J-Schrempf N: A keverés modellezése a vegyes anyagokat felhasználó biogáz üzemben Mezőgazdasági technika, 2015/8

5. Hajdú J., Magó L.: (2006) The Possibilities of Use of the Biomass in Hungary, Proceedings of the 34th Inter-national Symposium "Actual Tasks on Agricultural Engineering", Opatija, Croatia, 21-24. February 2006. Proc. p. 111-120. 